Journal of Southeast Asian

\title{
Book Review: Little Saigons by Karin Aguilar-San Juan
}

Betsy Maloney

University of Minnesota, betsysperrymaloney@yahoo.com

\section{Recommended Citation}

Maloney, Betsy (2011) "Book Review: Little Saigons by Karin Aguilar-San Juan," Journal of Southeast Asian American Education and Advancement. Vol. 6 : Iss. 1, Article 19.

DOI: $10.7771 / 2153-8999.1035$

Available at: https://docs.lib.purdue.edu/jsaaea/vol6/iss1/19

This document has been made available through Purdue e-Pubs, a service of the Purdue University Libraries. Please contact epubs@purdue.edu for additional information.

This is an Open Access journal. This means that it uses a funding model that does not charge readers or their institutions for access. Readers may freely read, download, copy, distribute, print, search, or link to the full texts of articles. This journal is covered under the CC BY-NC-ND license. 


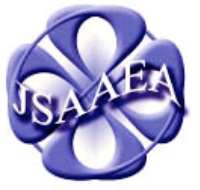

Volume 6 (2011)
Journal of Southeast Asian American

Education \& Advancement

WWW.JSAAEA.org
A peer-reviewed scholarly journal published by the National Association for the Education \& Advancement of Cambodian, Laotian, and Vietnamese Americans (NAFEA)

Aguilar-San Juan, Karin. (2009). Little Saigons: Staying Vietnamese in America. Minneapolis, MN: University of Minnesota Press. 248 pp. $\$ 22.50$ (Paperback). ISBN: 978-0-8166-5486-4.

\author{
Reviewed by \\ Betsy Maloney \\ University of Minnesota
}

Karin Aguilar-San Juan writes, "We long for home, yet many of us are so busy moving from place to place that no single place appears to have much impact on us" $(2009$, xi). So begins Little Saigons: Staying Vietnamese in America, a book exploring place-making and identity

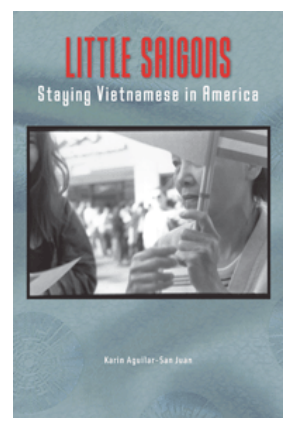
formation in Vietnamese American communities. Aguilar-San Juan, a professor of American Studies at Macalester College, situates immigrant experiences in two Vietnamese American communities (Fields Corner in Boston and Little Saigon in Orange County, California) as a constant reciprocal experience between landscapes, human-constructed places, relationships and memory. Her argument is clearly developed throughout the book: retaining one's identity in an American immigrant community requires more than simply passing down cultural traditions between generations or remembering the past by retaining one's language. Throughout the book's five chapters, the author suggests that in order to retain their Vietnamese identity and all that their past holds, Vietnamese Americans use elements of the physical domain as well as social relationships to reflect and preserve nuances specific to their Vietnamese histories.

For nearly ten years beginning in 1994, Aguilar-San Juan conducted interviews with Vietnamese American leaders and other experts living in Boston and Orange County. The stories she collected while interviewing residents form the foundation of the book's conclusions. Her commitment to these two communities over nearly a decade provides both the author and the reader with data that reflect place and time. Aguilar-San Juan's conclusions are also influenced by her personal history. As a daughter growing up in a Filipino American community, she developed an awareness of immigrant identity and its role in constructing place, presence and community early on in her life. Although an outsider to the Vietnamese American community, she nonetheless understands how immigrants in America are relegated to a marginalized position in society. Her "insider/outsider" perspective, carefully honed through two trips to Vietnam and countless interviews, reflects a unique perspective through which to explore the notion of immigrant identity.

\title{
@)
}

SOMERIGHISRESEREED Readers are free to copy, display, and distribute this article, as long as the work is attributed to the author(s) and the Journal of Southeast Asian American Education \& Advancement, it is distributed for noncommercial purposes only, and no alteration or transformation is made in the work. More details of this Creative Commons license are available at http://creativecommons.org/licenses/by-nc-nd/3.0/. All other uses must be approved by the author(s) or JSAAEA. 
In Chapter 1, Aguilar-San Juan presents readers with contextual analysis that identifies and situates themes important to her study of Vietnamese American communities. She examines the tenets of community, place making, migration and identity formation as they relate to two separate Vietnamese American communities: Fields Corner and Little Saigon. The data and subsequent analysis represented in Chapter 1 provide a focused base for readers to understand the physical and political factors influencing both communities. By the end of the section, readers understand how place, space and time converge in identity formation for Vietnamese Americans.

Aguilar-San Juan continues to lay groundwork for readers in Chapter 2 by discussing the tenuous intersection of Vietnam's history, policies of the U.S. government between 1960-1970, and the experiences of Vietnamese refugees who fled to America. Her critical analysis of American history during the years before and immediately after the end of the Vietnam War gives the author the opportunity to tease out the complex issues experienced by refugees who fled the war. She points out that in 1975, the term Vietnam became so synonymous with the Vietnam War that many Americans forgot the country of Vietnam ever existed. Newly arrived refugees from Vietnam, albeit small in numbers, collided head-on with the loud debate about America's involvement in the war, and this served to reinforce their invisible identity to most native-born Americans.

Aguilar-San Juan's focus shifts midway through Little Saigons from a historical/political perspective to the personal. In Chapter 3, readers learn how community members in both Fields Corner and Little Saigon use memory as a way to create space and place in their neighborhoods. Her conclusions in this chapter offer an intimate view of the individual in the larger context of community, and memory making serves as the bridge that connects these two points. AguilarSan Juan writes that Vietnamese Americans participate in "strategic memory projects" (pp. 6364) as a way to retain their Vietnamese identity. Community members coordinate physical spaces, fundraising events or memorial services that reflect memories of time past, which provides individuals within the Vietnamese American community a way to remember the country of Vietnam prior to America's chaotic entrance in the war. Memory making in these instances also becomes an opportunity to share history with younger generations who were born in the United States.

While the author's point is well made in this chapter, her decision to classify the memory making process as one that is indelibly "strategic" seems disjointed. In fact, the physical spaces and events themselves, to which the author refers in the book, seem to be the only thing that is "strategic." The experience of revisiting memories while attending a memorial service, for example, seems largely personal, subjective and "in the moment" - not strategic. After all, how can a memory-making experience, at both times personal and collective, be planned out, consciously created or otherwise formally produced as the term "strategic" implies? Isn't much of memory making an immediate response to one's surroundings? "Memories in progress" seem a more apt way to address the relationship between the past and the physical present in Vietnamese American communities. Just when the author seems to acknowledge the personal and spontaneous nature of memory making, instead of giving full agency to the memory maker, she goes on to suggest that ultimately most memories for Vietnamese Americans fight against the dominant culture's recollection of the Vietnam War and thus become the community's domain, not that of the individual.

An important aspect of Aguilar-San Juan's conclusions rests on the notion that physical space influences the development of identity. The author illuminates the ways in which space, 
place and social relationships assist Vietnamese Americans in staying Vietnamese throughout the book. As an example, the author profiles in Chapter 4 a contentious debate that erupted in Fields Corner. A local developer, Frank Jao, attempted to develop Harmony Bridge, a strip mall devoted to Asian American businesses. Vietnamese Americans living in the community were angered over the proposed development because they perceived that it would reflect a broader Asian American identity instead of becoming a physical space echoing Vietnamese American identity. The debate centered in part around Jao's own identity because he was Chinese American, not Vietnamese American. Thus, residents in the Vietnamese American community greeted his overtures with skepticism. Aguilar-San Juan's account of Fields Corner residents' raw emotional reaction to Jao is but one example in her book that places human attempts to form and/or retain identity against the physical construction of space.

A quick glance at the Notes section of the book reveals references to notable scholars who have contributed to the conversation on immigrant identity and place-making theories. Ideas first explored by early cultural theorists become pseudo-guide posts throughout the book, framing Aguilar-San Juan's research questions and conclusions. In Chapter 5, she writes, 'researchers have focused on the significance of 'ethnic' community ties, trust, geographic concentration, and in the case of ethnic Chinese entrepreneurs, links to overseas capital" (p. 123). Here, Aguilar-San Juan applies the work of Montero, Rutledge, and others to explain how social connections within each community influences the development of identity. In doing so, she places her work within the larger discourse on racialization and social capital. Interestingly, the focus of Aguilar-San Juan's research is an often-neglected subject for scholars, even for those interested in the Asian American experiences in America. Little Saigons thus becomes a treatise of sorts on the hegemonic forces disrupting Vietnamese American communities' attempts to retain their Vietnamese identity.

Despite many of its well-constructed structures and clear themes, Little Saigons exhibits a few problems. Aguilar-San Juan's method of research - interviews - seems a natural format to unearth ideas, attitudes and memories about the country of Vietnam, immigration to America and life in the United States for Vietnamese Americans. Indeed, researchers have long considered interviews a legitimate approach to inquiry. But Aguilar-San Juan relies on snowball sampling to find willing residents for interviews; interviewees recommended other individuals they knew to participate in the project. This method of referring colleagues or friends can potentially perpetuate shared values and experiences, thus skewing the data collected from the interviews. The tendency to mingle with individuals who share similar values and experiences, such as family members, affects how we see, interpret, and respond to larger societal mechanisms (Keister \& Moller, 2000). Possibly, the data gathered by Aguilar-San Juan may reflect only a thin stratum of the larger Vietnamese American community. Aguilar-San Juan might have taken a different approach to her interview process by enlisting the help of individuals representing a broader spectrum in the communities of her study.

Another area of concern is Aguilar-San Juan's assertion that she interviewed leaders within the community for the project. How did she and others define "leader?" Was it someone who held a position of authority in a community-based organization or network? Was it someone who was an elder in the community? Or, was it someone who enjoyed expansive support by Vietnamese Americans living in the community? These questions remained largely unanswered throughout the book, leaving the reader to wonder if everyone involved in the project, from the author herself to the community members living in Fields Corner or Little Saigon, agreed about the definition of a "community leader." Could self-identified leaders, possibly those who enjoyed 
a few more privileges in the community because of their status, accurately represent everyone's ideas?

Overall, Aguilar-San Juan's work in Vietnamese American communities provides much needed insight into immigrant communities in America, and Little Saigons would appeal to those readers particularly interested in immigrant identity formation. But more research is needed given the many questions that remain. For instance: How might gender, sexual orientation, age or class status affect ways that Vietnamese Americans stay Vietnamese? What happens when Vietnamese Americans living outside of Fields Corner or Little Saigon, away from large communities of Vietnamese Americans, attempt to retain their Vietnamese identity on their own, without the luxury of other members of their community to assist in the process? What community institutions in and around Boston or Orange County help community members preserve their Vietnamese identity? Readers can only hope that scholars like Aguilar-San Juan will continue researching Vietnamese American communities to better understand how this select group of people, a critical part of American past and present, experiences and contributes to the dynamic fabric of our country.

\section{Reference}

Keister, L. \& Moller, S. (2000). Wealth inequality in the United States. Annual Review of Sociology, 26, 63-81.

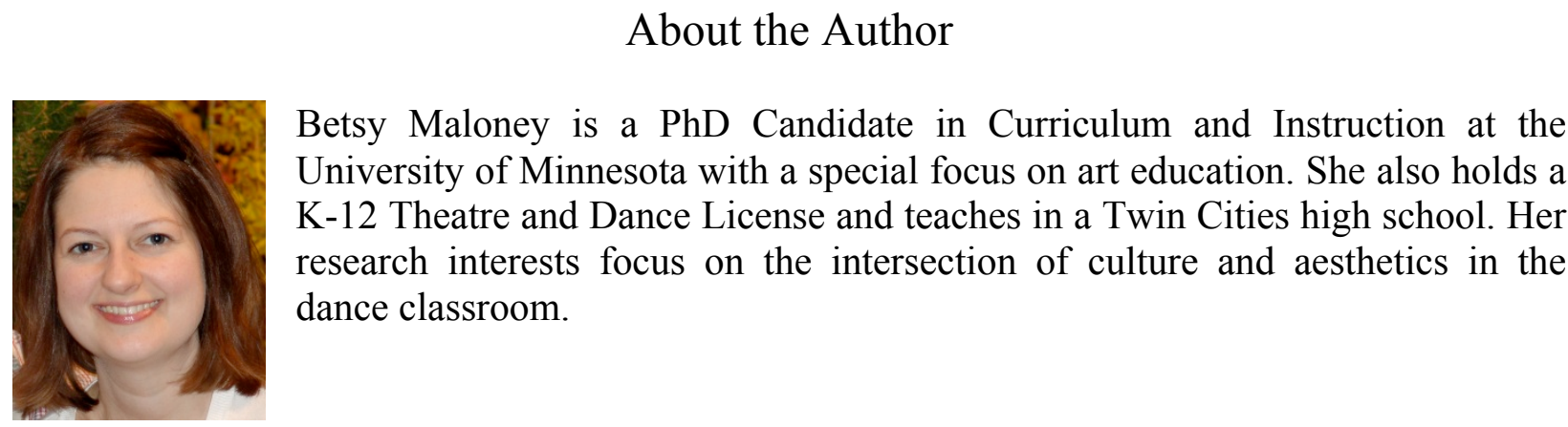




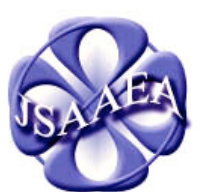

Volume 6 (2011)

\section{Journal of Southeast Asian American Education \& Advancement}

\author{
WWW.JSAAEA.org
}

\section{Editor}

Dr. Wayne E. Wright

University of Texas, San Antonio

\section{Associate Editors}

Dr. Chhany Sak-Humphry

University of Hawaii

Dr. KimOanh Nguyen-Lam

California State University, Long Beach

Book Review Editor

Dr. Vichet Chhuon

University of Minnesota

\section{Creative Works Editor}

Bryan Thao Worra

Lao Assistance Center

Special Advisor

Gregory Green

Curator, Echols Collection on Southeast Asia, Cornell University Library

Journal Manager

Sovicheth Boun

University of Texas, San Antonio
A peer-reviewed

scholarly journal published by the

National Association

for the Education \&

Advancement of

Cambodian, Laotian,

and Vietnamese

Americans (NAFEA)

Comments and questions for the editorial staff may be directed to jisaaea@lists.sis.utsa.edu

\section{Editorial Review Board}

\author{
Dr. Steve Arounsack \\ California State University, Stanislaus \\ Dr. Phala Chea \\ Lowell Public Schools \\ Dr. Loan Dao \\ Cancer Prevention Institute of California \\ Dr. Sophal Ear \\ U.S. Naval Postgraduate School \\ Dr. Nancy H. Hornberger \\ University of Pennsylvania \\ Dr. Peter Nien-Chu Kiang \\ University of Massachusetts, Boston
}

Dr. Carl L. Bankston III

Tulane University

Dr. George Chigas

University of Massachusetts, Lowell

Dr. Changming Duan

University of Missouri, Kansas City

Dr. Jeremy Hein

University of Wisconsin - Eau Claire

Dr. Samlong Inthaly

Minneapolis Public Schools

Dr. Kevin K. Kumashiro

University of Illinois, Chicago 


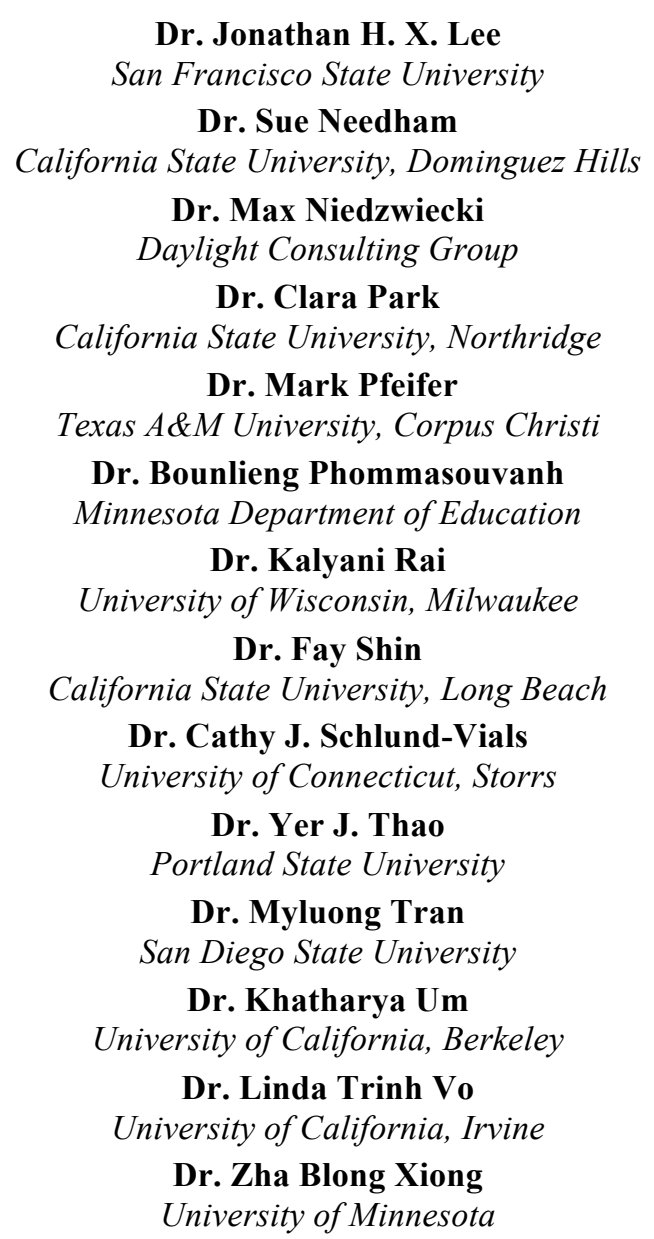

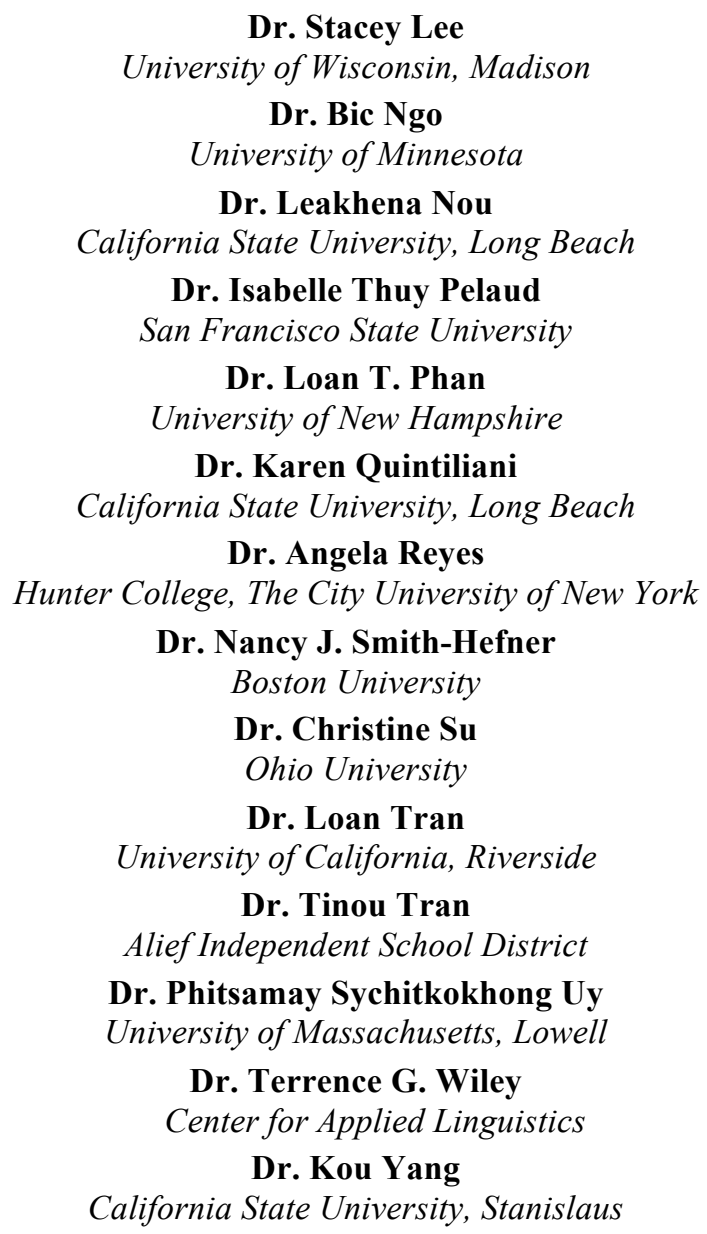

Dr. Stacey Lee

University of Wisconsin, Madison

Dr. Bic Ngo

University of Minnesota

Dr. Leakhena Nou

California State University, Long Beach

Dr. Isabelle Thuy Pelaud

San Francisco State University

Dr. Loan T. Phan

University of New Hampshire

Dr. Karen Quintiliani

California State University, Long Beach

Dr. Angela Reyes

Hunter College, The City University of New York

Dr. Nancy J. Smith-Hefner

Boston University

Dr. Christine Su

Ohio University

Dr. Loan Tran

University of California, Riverside

Dr. Tinou Tran

Alief Independent School District

Dr. Phitsamay Sychitkokhong Uy

University of Massachusetts, Lowell

Dr. Terrence G. Wiley

Center for Applied Linguistics

Dr. Kou Yang

California State University, Stanislaus

\section{Doctoral Student Editorial Review Board}

\author{
Keo Chea-Young \\ University of Pennsylvania \\ Ketmani Kouanchao \\ California State University, Fullerton \\ Polinda Keo \\ University at Albany \\ Ravy Lao \\ University of California, Santa Barbara \\ Thien-Huong Ninh \\ University of Southern California \\ Malaphone Phommasa \\ University of California, Santa Barbara \\ Rassamichanh Souryasack \\ University of California, Santa Barbara \\ Alisia Tran \\ University of Minnesota \\ Silvy Un \\ University of Minnesota
}

\author{
Annie BichLoan Duong \\ San Joaquin County Office of Education \\ Peter Tan Keo \\ Columbia University \\ Ha Lam \\ Arizona State University \\ Monirith Ly \\ Texas State University-San Marcos \\ Giang Pham \\ University of Minnesota \\ Vanna Som \\ Harvard University \\ Somongkol Teng \\ University of Minnesota \\ Krissyvan Truong \\ Claremount Graduate University \\ Yang Sao Xiong \\ University of California, Los Angeles
}

